\title{
3. Redistributing land in the Philippines: social movements and state reformers
}

\author{
SATURNINO M. BORRAS, JR AND JENNIFER \\ C. FRANCO
}

This chapter examines the national citizens' campaign for land reform in the Philippines. In a society such as the Philippines today, where land still connotes wealth and power concentrated in the hands of the few, land reform holds a great deal of political significance and generates intense political conflict. It is probably the only public policy area that continues to mobilize a range of pro- and anti-reform actors in both the state and civil society, and to encourage the rise of sustained strategic alliances.

The history of land reform in the Philippines has been marked by a pattern of periodic cycles of intense social mobilization in favour of land reform being met by a lukewarm state response and government inertia. Government accountability to poor rural citizens demanding land reform has never been automatic; nor have government promises of reform made under intense social pressure been enough to deliver real results. Instead, there has been a steady succession of promises broken and opportunities lost.

Yet this basic pattern has been broken. Despite a host of pessimistic predictions about the inherent flaws of the 1988 Comprehensive Agrarian Reform Programme (CARP), after an initial lag an unexpectedly positive trend in land reform implementation took hold. Between 1992 and 1998 , land redistribution took off and the momentum continued into the next presidential term, though at a diminishing pace. After 2001, government inertia reasserted itself, and since then implementation of the programme has lumbered on half-heartedly, suffering serious legal assaults on its scope and legitimacy. But, according to the government, by 20076 million hectares of private and public lands - about half of the country's farmland - had been redistributed to 3 million poor rural households, representing two-fifths of the agricultural population. In addition, 1.5 million hectares of land had been subjected to leasehold, benefiting about one million tenant-peasant households. ${ }^{1}$

The aggregate gains in land redistribution made during the 1992-98 
period are quite remarkable. And if one takes a close look at any one of the hundreds of individual land conflict cases from this period that were hard fought between an entrenched rural elite and tenant or farm worker claimants, and then won by the latter, the achievement becomes all the more remarkable (Franco 2008). It is precisely through such difficult political-legal struggles to control the meaning and purpose of the development process - waged both inside and outside state structures - that new collective identities and attitudes towards authorities are constructed at the grass roots. These identities and attitudes are potentially important indicators of democratization.

This, then, poses a question. If the Philippines has such a long and tarnished record in land reform, what explains the broadly unexpected outcome of partial but significant success in land reform during this particular time? This chapter examines the reasons behind and possible wider implications of the fact that slightly over half of Philippines' land reform accomplishment over the past thirty-five years was achieved during this one six-year period. Why did the central state carry out a redistributive land reform at the time when, globally, this type of public policy had been dropped from the agendas of most nation-states and international development institutions? What were the dynamics of interaction among the key actors in state and civil society, and between the two? What are the implications of insights from this case for our broader understanding of how citizens' participation in national policies can make a significant impact?

We argue that this unexpected outcome was mainly the result of the peculiar nature of state-society interactions around national policymaking and implementation during this period. We contend that the authoritative interpretation and implementation of agrarian laws is a very complex and perhaps unexpectedly open-ended process, which results from the actions and interactions of state and societal actors at different levels of the polity. In the late 1980s, the potentials of the land reform programme remained beyond the limits of many people's political imaginations, and much had to be rethought and then proved before positive momentum could begin. This momentum was not fuelled by willpower alone; rather, movement forward in land redistribution was the result of the ongoing strategic interactions of key actors and their chosen political strategies within changing yet specific historical-institutional contexts.

\section{Historical context of land reform}

The history of citizens' engagement with the state on land reform is characterized by cycles of resistance and acquiescence, independence 
and co-option, success and failure. Citizen engagement has always been marked by socio-economic and geographic diversity, as well as by pluralism in terms of political strategies. Such diversity and pluralism have shaped perceptions of what is desirable and possible. Agrarian unrest in particular is long-standing, going back to the Spanish colonial period (1565-1898) which saw the introduction of the concept of individual freehold private property in land. This concept laid the foundations for the development of land monopoly, which has persisted despite a long and variable line of agrarian reform initiatives (McCoy and de Jesus 1982); the government's own data showed that by 1998 'not more than five per cent of all families owned eighty-three per cent of farm land' (Putzel 1992: 27).

It was not until the twentieth century that notions of justice became firmly anchored in organized demands for land by the peasantry. Successive peasant uprisings not only spread the call for agrarian justice nationwide, but also kept pushing land reform on to the national government agenda; they also gave rise to political strategies aimed at pushing the state to respond to peasant demands in democratic ways. Over time this has led to getting land reform on the central state agenda, expanding its scope and deepening its legal basis, and pushing government to keep its promises. The significance of the current land reform programme cannot be understood without reference to this history of agrarian unrest, and rural poor Filipinos' increasingly focused and politically sophisticated struggle for agrarian justice. If this has been primarily about land, it has necessarily also been about expanding the existing limits to political democracy and democratic state-building.

Historically, social pressure from below increasingly pushed the Philippine state to respond with programmes that emphasized resettlement programmes involving land frontiers. This pattern of resettlement and repression, rather than redistribution (Abinales 2000), was the dominant character of programmes during the first three-quarters of the past century. By the 1960s, however, state response to renewed agrarian unrest began to move tentatively towards redistribution, introducing the possibility of progressive measures under the 1963 Land Reform Code, and an agrarian reform programme which followed a decade later under the authoritarian regime of President Marcos. This programme's failure to deliver wide reform (Boyce 1993) fanned the flames of agrarian unrest and heightened peasant demands for justice. By the early 1980 , peasant protest had spread across the country, largely in the form of a Maoist-inspired revolutionary movement. It is partly because this movement played a key role in linking and mobilizing the anti-dictatorship 